\title{
Archives management in Pasimasunggu Timur Sub-District Office, Selayar Islands Regency
}

\author{
Zulfitriani $^{1}$, Sirajuddin Saleh ${ }^{2}$, Muh. Nasrullah $^{3}$ \\ 1,2,3 Universitas Negeri Makassar \\ E-mail: Fitrianisly@gmail.com
}

\begin{abstract}
Archives play an important role for the smooth running of offices. This study aims to determine the Management of Archives at the East Pasimasunggu District Office Selayar Islands Regency. This study used a qualitative descriptive approach with 5 informants. Data collection uses observation, interview and documentation techniques. While the data analysis technique used consists of four ways, namely: data collection, data reduction, data presentation, and drawing conclusions. The results of this study indicate that archival management at the East Pasimasunggu District office of the Selayar Islands Regency is in a fairly good category. This is demonstrated through the focus of research, namely: the creation of the archive is in the good enough category, the use of the archive is in the good enough category, the storage of the archive is in the good enough category, the maintenance of the archive is in the not good category, the shrinkage and destruction is in the not good category.
\end{abstract}

Keywords: Archives, archivists, employees

\section{INTRODUCTION}

The archive has important value and role because the archive is official evidence regarding the administration of government administration in the context of efforts to improve the effectiveness and effectiveness of the administration of the state apparatus. The purpose of archival activities carried out by the government is intended to ensure the safety of national accountability materials regarding the planning, implementation, and administration of national life and to provide these accountability materials for government activities.

Letters or important documents in an organization or government agency certainly require the filing process in it, the filing process is the basis of maintaining important letters and documents, so that with the archiving, both letters and important documents that have been stored previously can be easily rediscovered. The collection of letters is an important source of information for each administrative activity.

Records management has the aim to make it easier if one day the archive will be used (Dewi, Amirullah, \& Darwis, 2015; Saputri, Tambe, \& Darwis, 2015). Records management activities include recording, structuring, storage, maintenance to depreciation (Husain, Amirullah, \& Saleh, 2015). Records management activities always develop in accordance with the times and the development of organizational goals. One of the factors that cause archive management activities to continue to grow is the number of records that also continues to grow without being matched by good maintenance can cause employees to experience difficulties 


\section{4| Jurnal Office: Jurnal Pemikiran Ilmiah dan Pendidikan Administrasi Perkantoran Vol. 5, No. 2, July-December 2019, Hal 43-50}

when they will find the archive again (Hakim, 2015; Latif \& Pratama, 2015; Masykur, Makruf, \& Atmaja, 2015; Meirinawati \& Prabawati, 2015). Under these conditions, records management must be carried out in accordance with good procedures so that records can be easily found again. To guarantee the availability of authentic and reliable archives, guarantee the protection of the interests of the state and the rights of the people's civilization, as well as dynamize the filing system, archiving is required in accordance with the principles, rules and archival standards as required by a reliable national archiving system. (Undang-undang Nomor 43 Tahun 2009 tentang Kearsipan, 2009).

Based on the results of observations made at the East Pasimasunggu District Office of Selayar Islands Regency, it shows that the management of archives in the office is still not optimal. Not yet optimal management of archives can be seen from a number of issues the authors observe such as the difficulty of recovering the archives that will be needed. It took more than 30 minutes to find the required files again. Unorganized handling such as archives is stacked without being recorded in advance, the unavailability of archivists or people who have expertise in the field of archives, as well as the continuous increase in records without being followed by shrinking archives.

\section{METHOD}

This research approach is a qualitative approach, while the focus of research is the management of archives in the Pasimasunggu Timur Subdistrict Office of the Selayar Archipelago District which consists of receipt of archives, use of archives, archival storage, maintenance of archives and depreciation of archives. The stages of the study consisted of three steps, namely the stage before the research, the stage of fieldwork and the stage of data analysis (Niswaty, Juniati, Darwis, Salam, \& Arhas, 2019; Saleh \& Arhas, 2019). The informants consisted of the sub-district head, the sub-district secretary, and employees who worked in the Pasimasunggu Timur District Office of the Selayar Islands Regency. Data collection techniques used are observation, interviews, and documentation, while data analysis techniques used are data collection, data reduction, data presentation, and conclusions. Next test the validity of the selected data is the triangulation test.

\section{RESULT AND DISCUSSION}

The study was conducted at the East Pasimasunggu District Office of the Selayar Islands Regency with five informants. This study obtained based on research instruments researchers conducted on informants in the form of interviews, observations, and documentation. Analysis of this data includes; archive creation, use of archives, archival storage, maintenance of records, and, depreciation and destruction of records. Research data can be described as follows: 


\section{Archieve Creation}

Archival management activities begin with the creation of archives. Archives are created or later use as a medium for delivering information. Archives come from internal and external office archives. Office internal and external records are created when an office sends/receives letters/other documents. One of the activities in the creation of archives is the receipt of records in which the activities receive incoming letters that are grouped before being recorded, with this same thing done at the East Pasimasunggu District Office of Selayar Islands Regency. Each archive receipt is grouped before being recorded. With this record, it is hoped that it will expedite the process of organizing records. As a letter/document that is very important so that it becomes one of the implementers of the activity.

In managing archives, professional archivists are needed so that the implementation of archive processing can be done properly and do not conclude errors in managing archives, but the archive manager at the East Pasimasunggu District Office, Selayar Islands Regency is not an archivist because there are no employees with an educational background in archiving. Employees do not understand records management yet, employees hope that there must be training on records that all employees participate in so that they understand and do not make mistakes in managing records.

The creation of archives in terms of archivists in the East Pasimasunggu District Office of the Selayar Islands Regency is in a bad category, it appears that in the East Pasimasunggu District Office the Selayar Islands Regency there are no staff with archival backgrounds.

\section{Use of Archieves}

The use of archives constitutes the activities of utilizing and providing records for the benefit of the use of archives that are entitled. The use of archives is the second stage of managing records. In terms of the use of records, sometimes employees borrow files for use, but often result in lost records because employees who borrow sometimes return improperly. In addition, employees do not know the procedure to use the archive so if you want to use the archive do not use the procedure but employees who need the archive, immediately take the archive.

The use of archives in terms of archival management in the East Pasimasunggu District Office of the Selayar Archipelago Regency is in the quite good category, it appears that the use of the archive has been done and can help in solving problems.

\section{Archieve Storage}

Archive storage is one of the supporters of the success of the archive manager. Researchers describe the results of research regarding the storage of records ranging from the implementation of storage, storage systems, equipment, equipment, rooms, and environmental conditions archive storage. Archive storage is done by storing the archive in the closet. Then the storage is according to the date of the archive. The storage system used uses a date system, a dating system that is based on the date on the archive. Archive storage equipment owned 


\author{
46| Jurnal Office: Jurnal Pemikiran Ilmiah dan Pendidikan Administrasi Perkantoran \\ Vol. 5, No. 2, July-December 2019, Hal 43-50
}

includes cabinets and filing cabinets, while the equipment that is owned includes folders, file covers, instructions, and labels.

Archive Storage at Pasimasunggu Timur Sub-District Office in Selayar Islands Regency is quite good because of the availability of some equipment and equipment used for archival storage so that it can help easily recover the required records quickly and can help speed up office work.

\title{
Archieve Maintenance
}

Maintenance of records in the organization is one of a series of records management activities. According to the results of observations made at the East Pasimasunggu District Office regarding maintaining archives, no time has been determined for cleaning up archives and archives are usually cleaned using a feather duster. The archive is stored in a file box so that the archive is not cluttered. Maintenance of archives is still experiencing obstacles such as archives that are not maintained in accordance with good management. There are still many archives that are rarely cleaned and dusty in the cupboard, there are even files that are eaten by insects, even though the files eaten by these insects are in the important archive category

Based on the results of interviews that have been conducted regarding archival maintenance at the East Pasimasunggu District Office that archival maintenance is carried out in an uncertain time and there is no specific time for archival maintenance. Archive maintenance is done by cleaning with a tool in the form of a feather duster.

\section{Archieve Depriciation}

Archieve depreciation is important in the organization because it is one of a series of records management activities. Depreciation of the archive is done with the aim to control the flow of the archive that was created in a planned manner and save the archive as evidence of accountability. In accordance with the results of observations that have been made at the East Pasimasunggu District Office that there has been no archive shrinkage that has been carried out so that there has been a build-up of the number of records in each work table because the archive storage has begun to be full.

There are no employees who are experts in the field of archives because the archives are already in the category of inactive records, no shrinkage is done so that new archives, which are still active, actually have a mess on the work desks. The activity of depreciation of the archive has not been done so as to cause the volume of records to be out of control. Based on the results of interviews and observations, the depreciation of the archives at the East Pasimasunggu District Office of the Selayar Archipelago District was classified as poor implementation so that this resulted in the piling up of files and hampering the work of employees. 


\section{Discussion}

\section{Archieve Creation}

The receipt of the activity archive receives incoming letters that are grouped before being recorded, with the same thing being done at the East Pasimasunggu District Office of the Selayar Islands Regency. Each archive receipt is grouped before being recorded. With this record, it is hoped that it will expedite the process of organizing records. As a letter/document that is very important so that it becomes one of the implementers of the activity.

Based on observations and interviews on activities in the receipt of records carried out by employees there is a special grouping of incoming and outgoing special letters so that the implementation of archive processing has been going well seen from each incoming and outgoing letters checked first, so that the archives are really carried out based on its function. Besides that managing, the archive at the East Pasimasunggu District Office of Selayar Islands Regency is not an archivist in the sense that the person entrusted in managing the archive is an ordinary employee or ordinary staff. and for employees who are not yet professional in archiving management it is better to follow a kind of training so that they can know the procedures for managing archives in the Pasimasunggu Timur District Office in Selayar Islands Regency in accordance with operational standard procedures in managing records that have an organizational structure in managing archives.

\section{Use of Archieves}

The use of archives constitutes the activities of utilizing and providing records for the benefit of the use of archives that are entitled. Likewise, the use of archives at the East Pasimasunggu District Office of the Selayar Islands Regency was used to help solve the problem.

Based on observations at the East Pasimasunggu District Office in Selayar Islands Regency, archives are often used to help in solving problems, but sometimes the files used are borrowed by other parts such as letters and documents. But often the problem arises from borrowing records because employees sometimes take direct records without borrowing in advance and this can result in records being easily lost or scattered.

\section{Archieve Storage}

Archive storage is one of the supporters of successful archival management. Researchers describe the results of research on archival storage ranging from implementation, storage, storage systems, equipment, equipment, and archive storage rooms.

Regarding the implementation of archival storage in the East Pasimasunggu, District Office carried out by means of archives that have been processed or followed up and then stored in a place that has been provided. The storage system used in the East Pasimasunggu District Office uses a dating storage system based on the date on which the archives are stored. Archive storage equipment is one of the determining factors in the success of records management. The purpose 


\section{8| Jurnal Office: Jurnal Pemikiran Ilmiah dan Pendidikan Administrasi Perkantoran Vol. 5, No. 2, July-December 2019, Hal 43-50}

of the archive storage equipment is that the records can be neatly organized and always ready when the records are needed for the benefit of the organization. Based on the results of research that have been carried out it can be seen that the archive storage equipment owned by the East Pasimasunggu District Office includes a filing cabinet and filling cabinet that is starting to fill up to accommodate all the archives. In addition to the main equipment for archival storage, it is also necessary to provide equipment for archival storage. In accordance with the results of research that has been carried out, it can be seen that the archive storage equipment owned by the East Pasimasunggu District Office includes maps, instructions and labels. The equipment is to facilitate the storage of records and reduce the occurrence of damage and loss to the archive. Based on the results of research through observations that have been made to the archive storage room in the East Pasimasunggu District Office regarding the archive storage room is still one with the workspace of employees in each field.

\section{Archieve Maintenance}

Archives have a very important role as a source of information in an organization. The existence of archives, of course, must be maintained and maintained properly. Archive damage that occurs is caused by two factors, namely the intrinsic factor and extrinsic factor. The intrinsic factor is the cause of damage to files originating from the archive itself, such as the influence of ink, paper with poor quality, and others. While the extrinsic factor is damage to the archive caused by outside the archived objects, such as dust, mold, rats, insects or because of human actions such as cigarette embers. Maintenance of records can use a feather duster, broom, cloth, and preventive measures to put a ban on not smoking in the archive room.

Based on the results of interviews and observations that have been made regarding the maintenance of the archive in the East Pasimasunggu District Office has not been so noticed. This is because there are no special employees serving as archivists. Maintenance of records is carried out by each employee and concurrently the main tasks that must also be completed. Maintenance of archives only uses feather duster. Archival maintenance time is also uncertain when the archive looks dirty, new employees clean or tidy up the archive.

\section{Archieve Depriciation}

Archived depreciation is carried out by the organization due to avoid the accumulation of records that occur because of the increasing number of archive volumes. The buildup of records can hamper other work and also inefficient places, rooms, and even the organization's budget. Archives have their respective ages according to the use-value of the archive. Archives that have no use-value can be depreciated.

Depreciation of the archive in the East Pasimasunggu District Office has never been done, so there is an accumulation of records due to the large volume of archives. Actually it disturbs the performance of archives, but the employees themselves also object if they have to sort out archives that are already mixed with archives that are still active with archives that are already inactive. 


\section{CONCLUSION}

Based on the results of the study, archival management at the East Pasimasunggu District office in the Selayar Archipelago Regency is in a fairly good category. This is demonstrated through the focus of research, namely: the creation of the archive is in the good enough category, the use of the archive is in the good enough category, the storage of the archive is in the good enough category, the maintenance of the archive is in the not good category, depreciation is in the not good category.

\section{REFERENCES}

Dewi, C., Amirullah, A. H., \& Darwis, M. (2015). Efektivitas Pengelolaan Kearsipan pada Kantor Kementerian Agama Kota Makassar. Jurnal Office, 1(1), 18-23.

Hakim, T. D. (2015). Pengelolaan Arsip di Era Teknologi Informasi. Jurnal Ilmu Budaya. https://doi.org/10.31849/jib.v11i2.1102

Husain, L., Amirullah, A. H., \& Saleh, S. (2015). Efektivitas Pelaksanaan Pelayanan Kearsipan Pada Dinas Pendidikan Provinsi Sulawesi Selatan. Jurnal Ad'ministrare: Jurnal Pemikiran Ilmiah dan Pendidikan Administrasi Perkantoran, 2(1), 46-52.

Latif, F., \& Pratama, aditya wirangga. (2015). Perancangan Sistem Informasi Manajemen Arsip Elektronik. Jurnal Akuntansi,Ekonomi dan Manajemen Bisnis.

Masykur, F., Makruf, I., \& Atmaja, P. (2015). Sistem Administrasi Pengelolaan Arsip Surat Masuk Dan Surat Keluar Berbasis Web. Indonesian Journal on Networking and Security.

Meirinawati, \& Prabawati, I. (2015). Manajemen Kearsipan untuk Mewujudkan Tata Kelola Administrasi Perkantoran yang Efektif dan Efisien. Administrasi Perkantoran.

Niswaty, R., Juniati, F., Darwis, M., Salam, R., \& Arhas, S. H. (2019). The Effectiveness of Leadership Functions Implementation in The Makassar Departement of Manpower. JPBM (Jurnal Pendidikan Bisnis dan Manajemen), $5(1), 1-10$.

Saleh, S., \& Arhas, S. (2019). The Effect of School Head Academic Supervision on Pedagogic Capability of Basic School Teachers in Manggala District Kota Makassar. International Conference on Social Science 2019 (ICSS 2019). Atlantis Press.

Saputri, I. A., Tambe, M. N., \& Darwis, M. (2015). Efektifitas Pengelolaan Kearsipan 
50| Jurnal Office: Jurnal Pemikiran Ilmiah dan Pendidikan Administrasi Perkantoran Vol. 5, No. 2, July-December 2019, Hal 43-50

pada Kantor Sekretariat Daerah Kabupaten Gowa Provinsi Sulawesi Selatan. Jurnal Office, 1(2), 153-159.

Undang-undang Nomor 43 Tahun 2009 tentang Kearsipan. Arsip Nasional Republik Indonesia. , (2009). 